\title{
Э.И.Богдинов, Ф.В.Тахавиева
}

\section{МЕТОДИКА ВОССТАНОВЛЕНИЯ ДВИГАТЕЛЫНЫХ ФУНКІИЙ У БОЛЬНЫХ В ОСТРОМ И РАННЕМ НОССТАНОВИТЕЛЬНОМ ПЕРИОДАХ MOЗГОВОГО ИНСУ JЬTA}

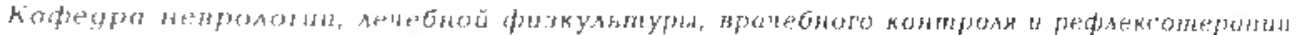

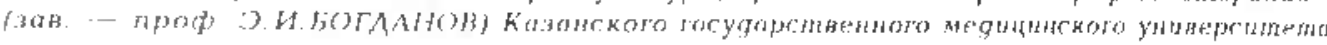

Di]

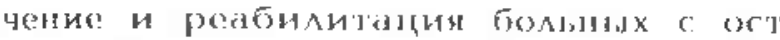

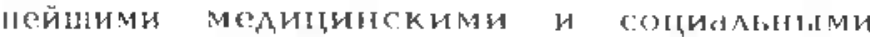

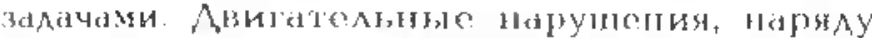

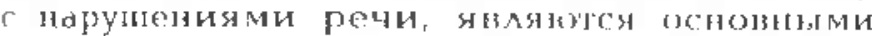

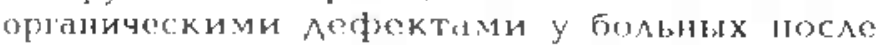

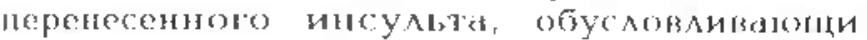

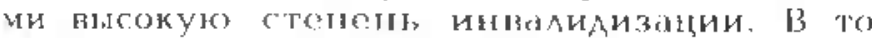

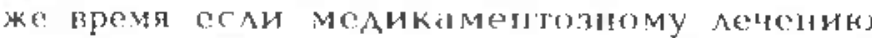

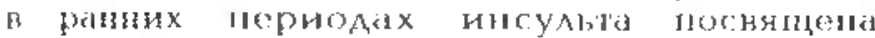

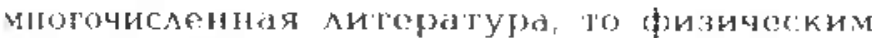

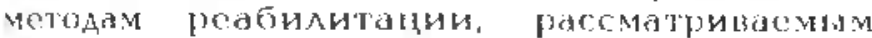

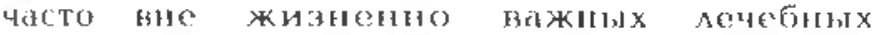

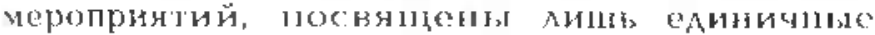

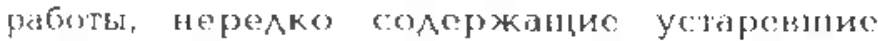

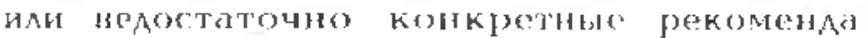

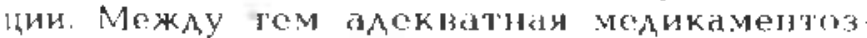

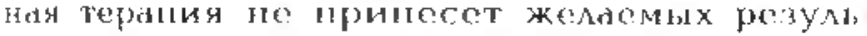

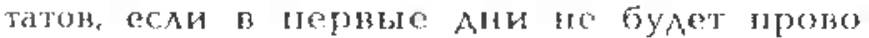

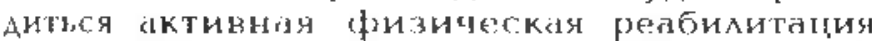

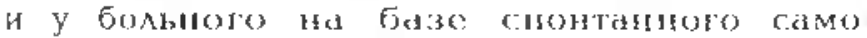
обучения сфолымируктея шытологические ус

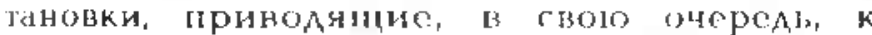

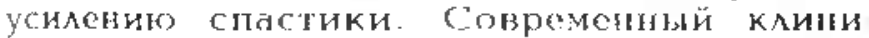

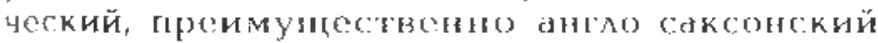

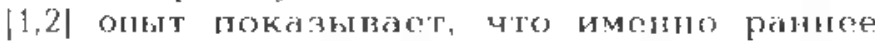

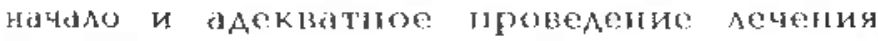
положением и кинезиотерания обеспечива

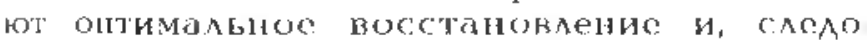
вательно, огределянт булушіе "качестно

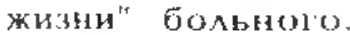

Аечение положснием и кинезиотерания

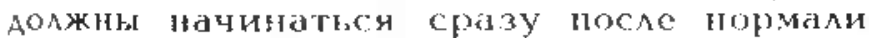

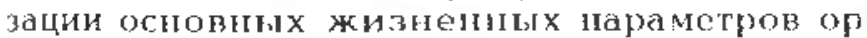
ганизма, обеслечивая, наряду с Арулими ме? рогриятиями, прингцт: एєабилитапия 244 в сутки.

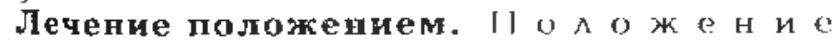
H a II $U$ $\mathrm{p}$ a н $е$ - самая нажная $170 з$ вияя и Аолжиа

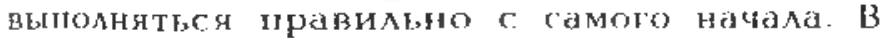

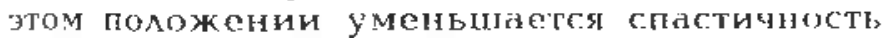
и увеличннается чувстнительеотты поражен ной стороны, преимулшеством Іакжс явля ется осичбожление зяюровой руки Аля самообслужнвания. Голына Аолжна быты В УАОбном ІІоложениИ - Состонние ФАексин

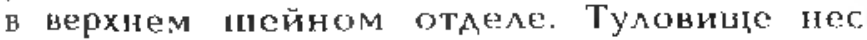

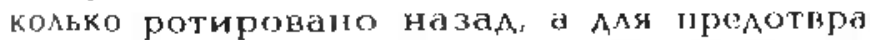
цения Авижения нाереА персд папиентом подКАадвастся Подупाка. Пораженная рука вытянута впереА и лежит поА углом $90^{\circ} \mathrm{k}$ туловину. ГІІредплечье суниниронано, кисты,

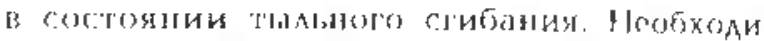

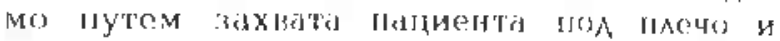

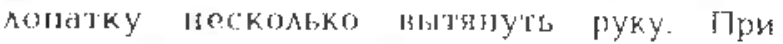

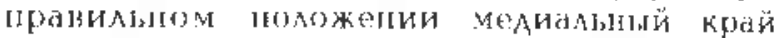

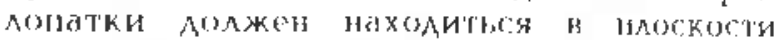

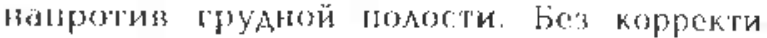

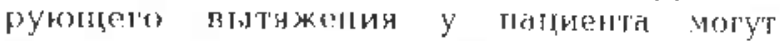

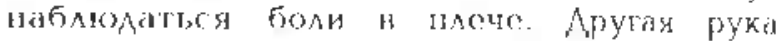
н

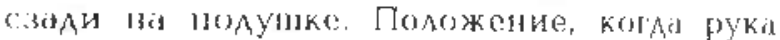

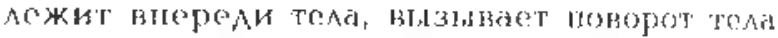

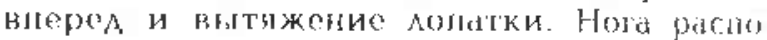

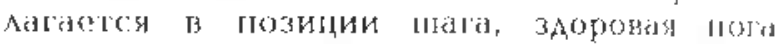

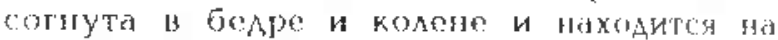

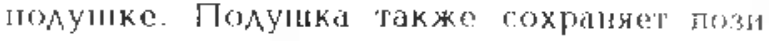

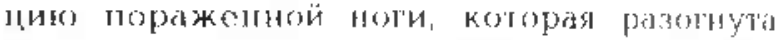

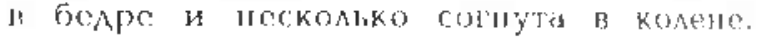

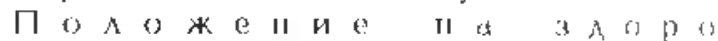

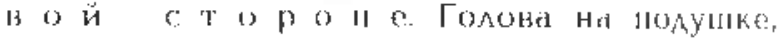

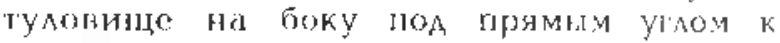

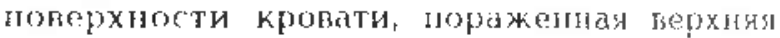

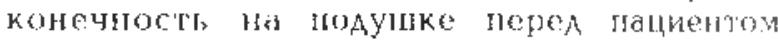

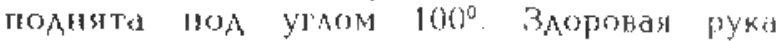

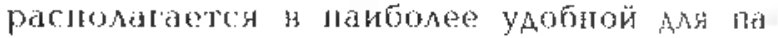

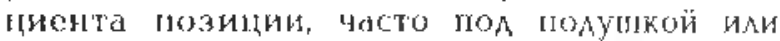

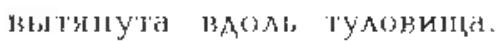

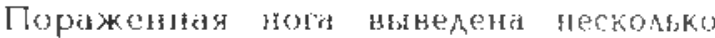

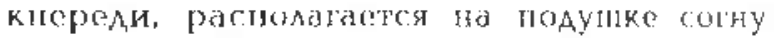

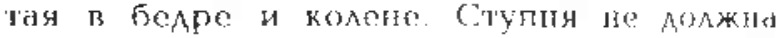

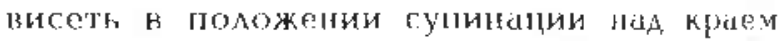
Isодугики. Аруган пгга в положения неко

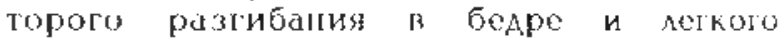
сгибаIин в коленमом сус'Гаве.

П

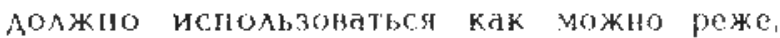

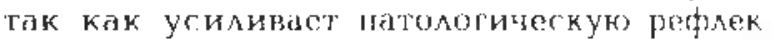

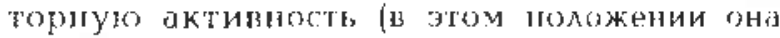

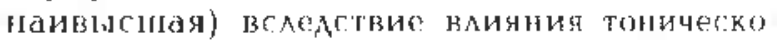
го пейльго и лабиринтного рерлексон.

Голова улобно располатается Ha IолуI ке, чри этом НеобХОАКМо САЕАНТЕ, чтоб̆н

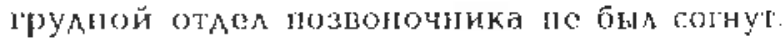
Подугтка растолагастся дом пораженлой ягодицей и бедром Аля наклона таза кпереди, что шрепятствуст науружной рога циин Ізоги. Подугіка

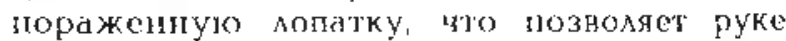
њаходиться В эравиАьном положении, те. при разогиутом локтевом сустане и тыль ном слибании лучезалястного сустава РекоменАуется периодически на Некоторое времн зитягивать руку нал головой (ңеко торые [ациенты используют эту позицик при чтении). Ноги вытязуті. Подлерживаю 


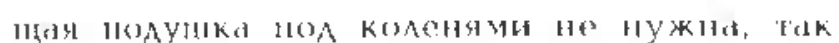

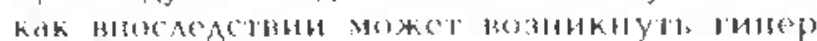

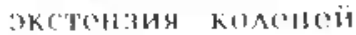

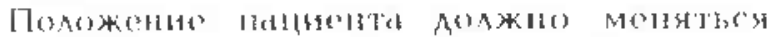

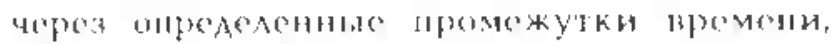

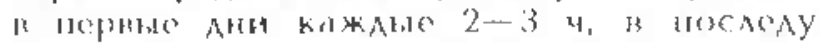

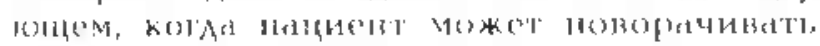

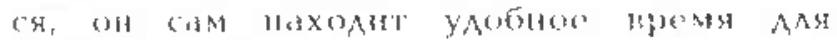

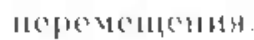

Стимуляцинейромоторных функщий. I

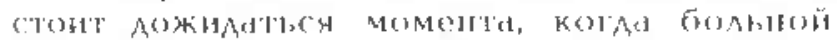

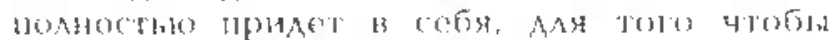

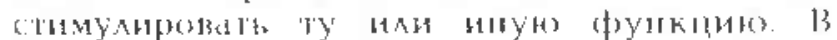

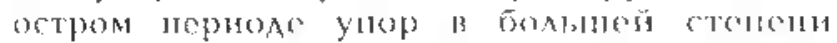

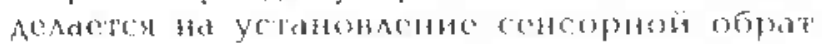

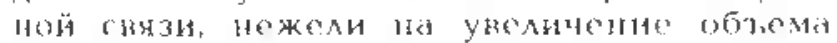

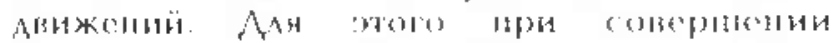

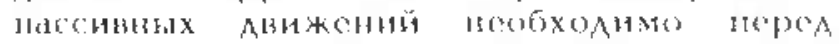

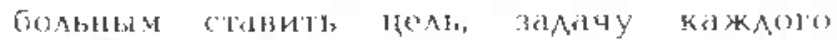
Асйстиин

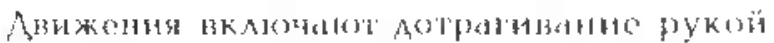

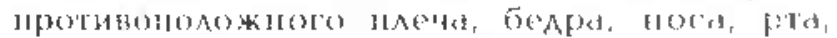

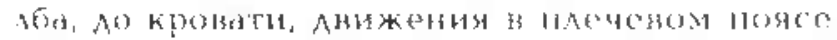
H 'T'A

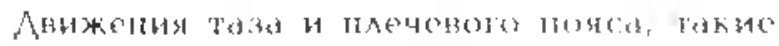

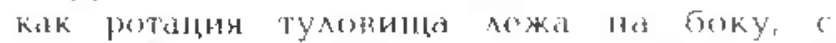

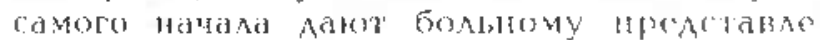

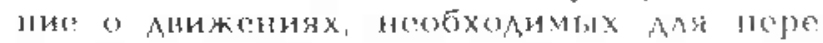

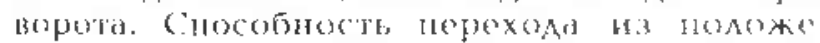

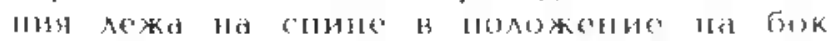

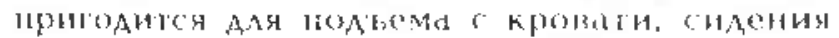

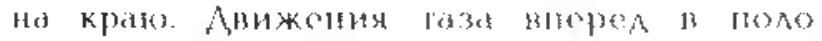

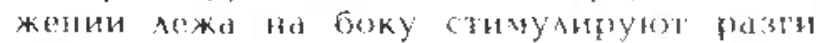

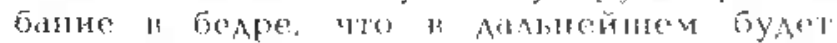

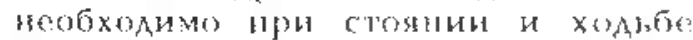

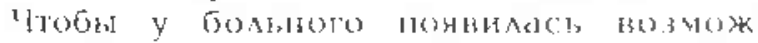
HOCL, Aуз

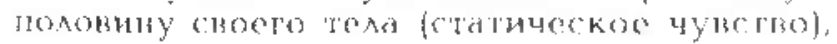

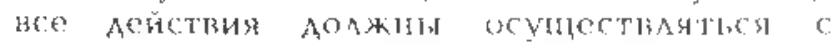

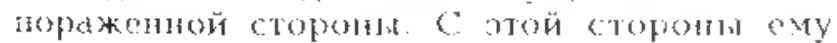

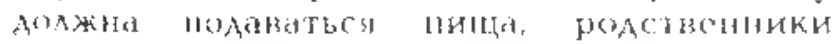

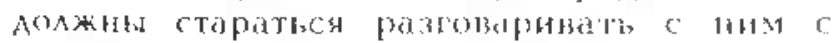

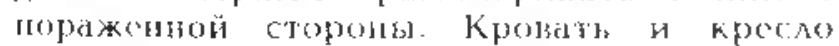
Аолжыb располагатlся Таким образом,

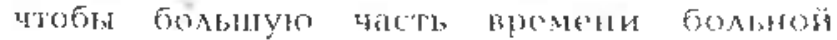

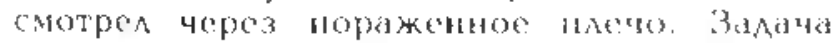

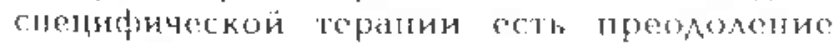
"тространствениой однобокости", пореори

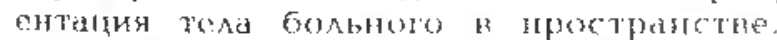

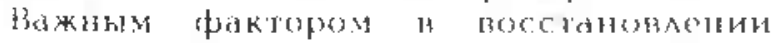

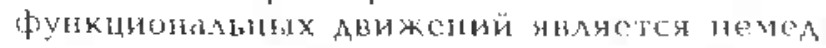

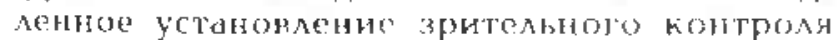
за своими руками и бблектом, до которого нужня лотронуген. Зрительная обратыня

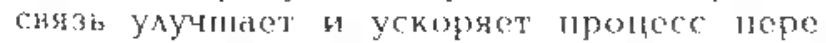
обучения, 110зволяет поцненту нолучиг,

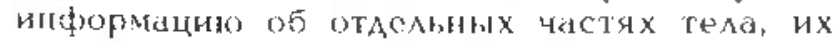
њз九имоотнонениях, пространствениой орга низации - всего того, что наруйется при инсуяьтах

Стимуляция переноса веса тела и тревировка равновесия. В первыс Ани после нормализацин основных жизненных нара метроп необходимо Аат, нозможность боль ному гротивостоять сияе гравитации. Из

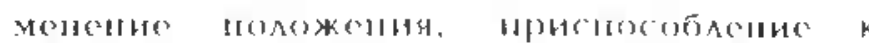

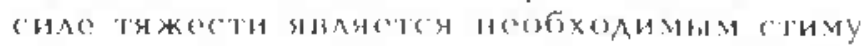

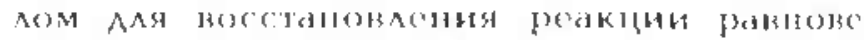

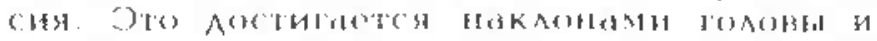

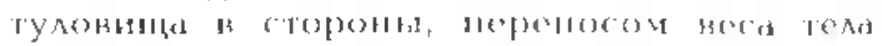

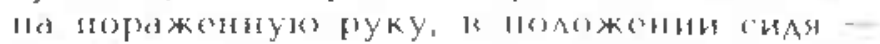

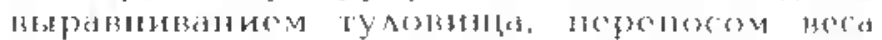

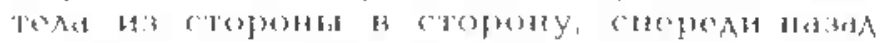

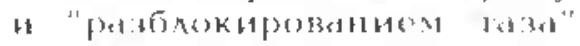

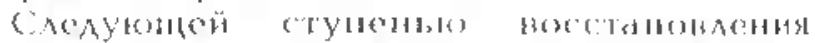

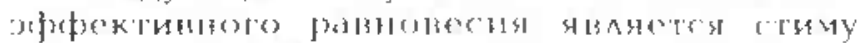

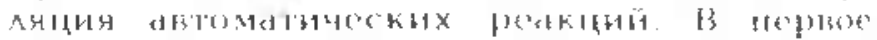

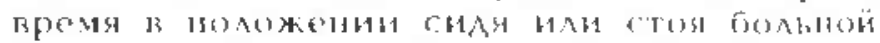

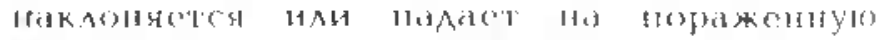

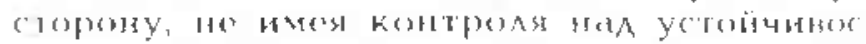

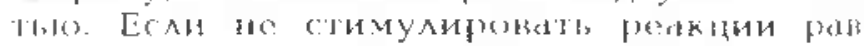

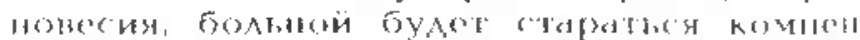

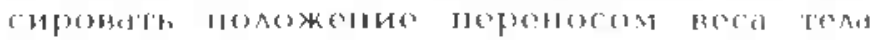

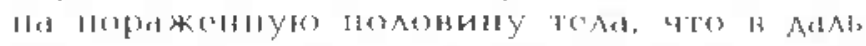

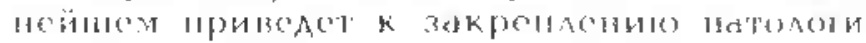

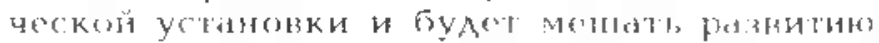
la Bat

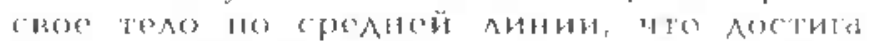

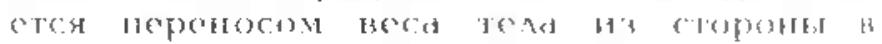

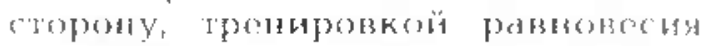

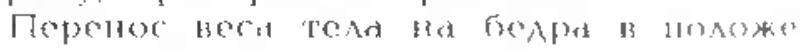

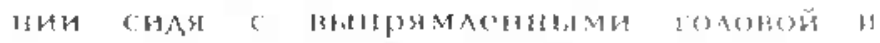

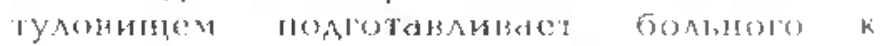

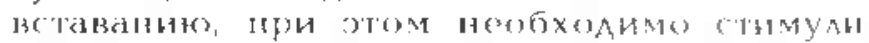

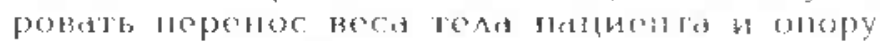

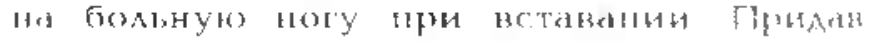

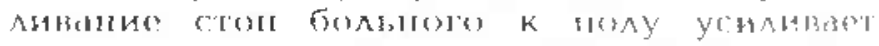

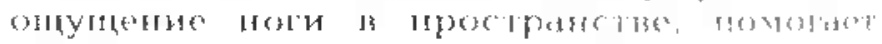

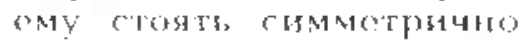

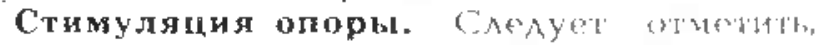

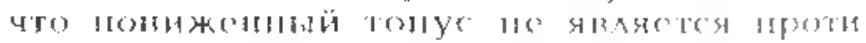

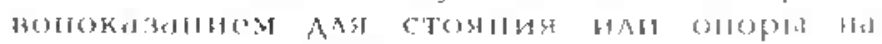

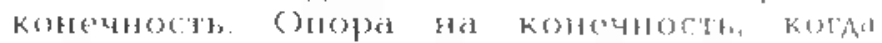

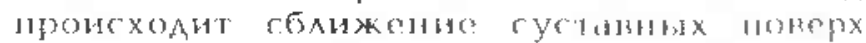

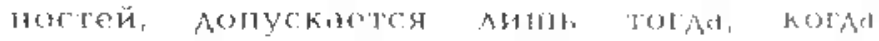

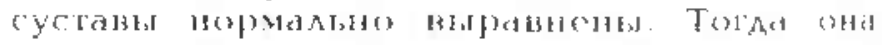

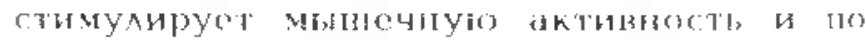

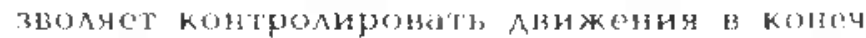
ности. Сенсорная стимуляңня Тактильных

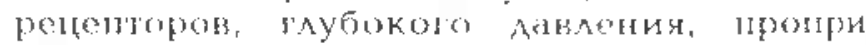

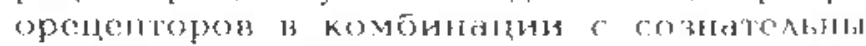
ми roll,

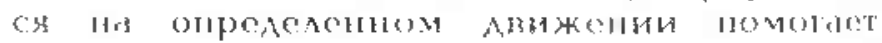

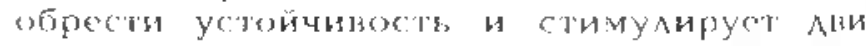
жение

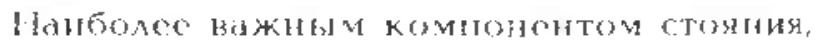

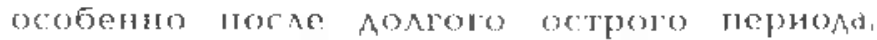

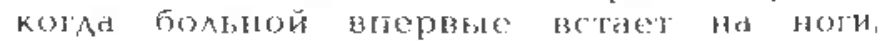
янляется экстензия белра, Оте Позволяет

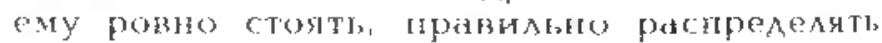

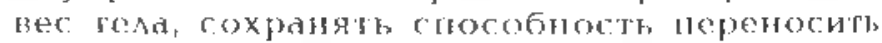
вег тела с ноли lia nory. Если с этим у

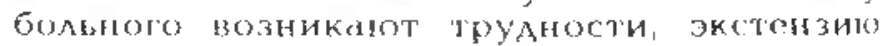
бедра можно стимуляроваты в положении

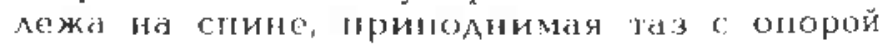
Ha Hory

13 случае нестабнлғности в коленном суставе иiона целегообразно прнменение слециальных фикекторон, позноляницих боль 


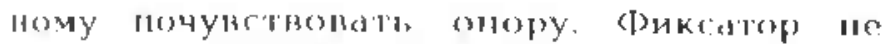

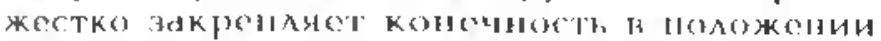

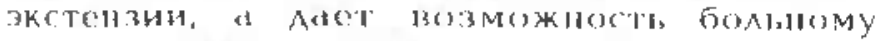

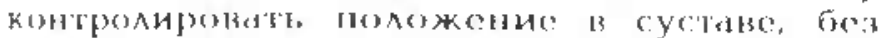

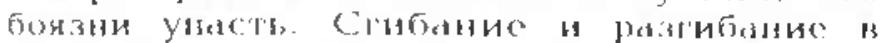

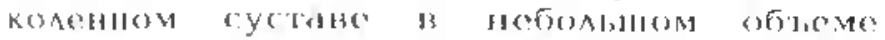

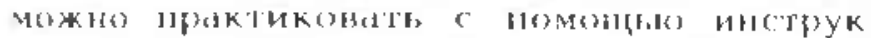

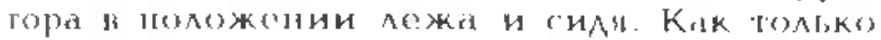

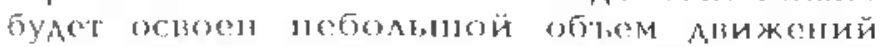

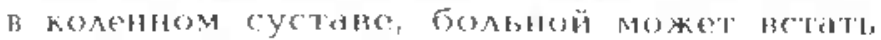

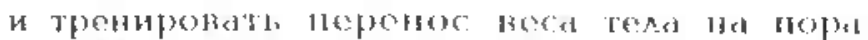

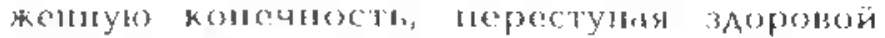

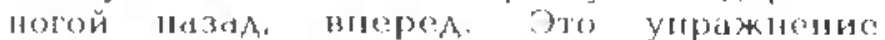

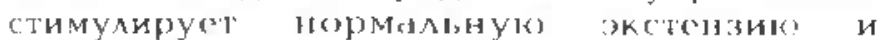

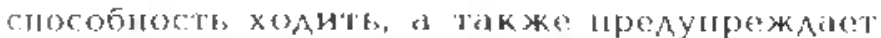
разиитие слатстки.

Предупреждевие спастикя. Стимуягия

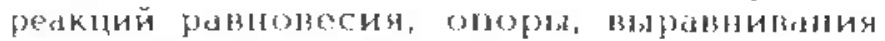

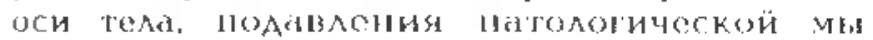
нечной актизности познольет (иести $\mathrm{K}$

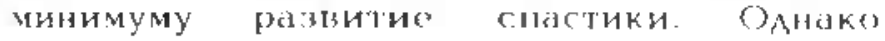

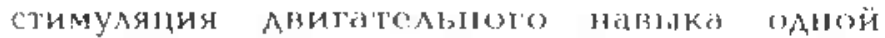

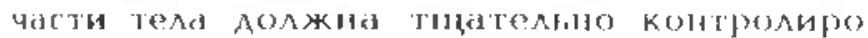

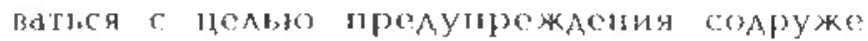

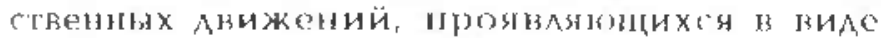

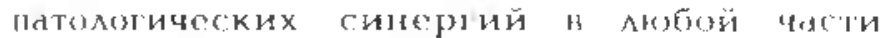

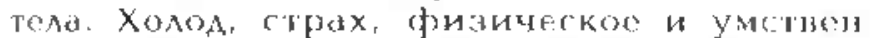

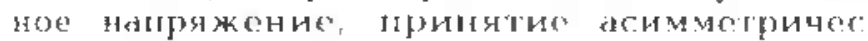
кой позғ стимулиует патололическое

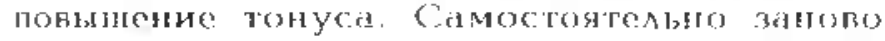
обучаяс, Ходубе, गатиент стілкинатея с

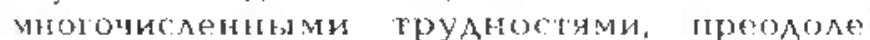

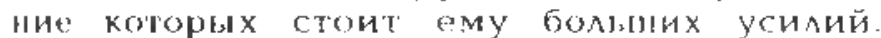

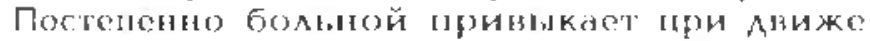

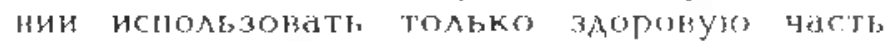

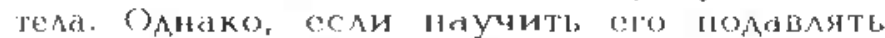

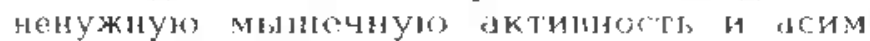
метритногть миижения, следит, и коррек

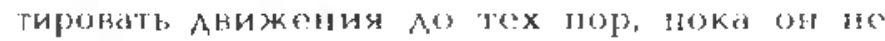

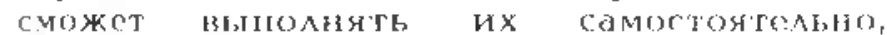

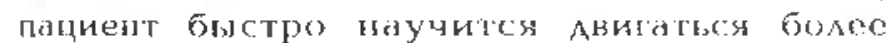
зффективно. Годандение титерактинекой зАоровой стороны янляется, наверное, наи более значимьг фактором прслупреждения гилертонуса па пораженной стороне, что В

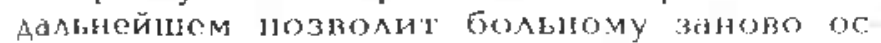
ноить симметричныс Iғаныки.

Еще оАним фактором, ндиялџци ла тонус, нвляется беслокойство. Необходимо сня'ть беслокойстно и напряжение пациен та, обратив внимание на пІоднтые плечи, зажатун позу, пролложит больному рас слабитея. Кроме физических методов преодоения и тредугрежления спастики мाггие пациенты НужАантся н СПециальны психологических метолах релаксации

Лечение гиперronyca не должно pac сматриваться н отрыне от каждого конкрет ното случая, от пациента и его џроблем, однако есть ряА обШих пунктов, котюрых нало Придерживаться в работе. Во 11ервнх, нужно избегат, гірименения методов и техлик, повышаюцих тонус, таких как

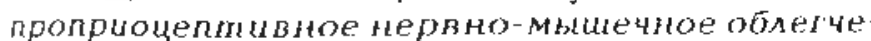
ние, изометричсские гимнастики, иғытлняс

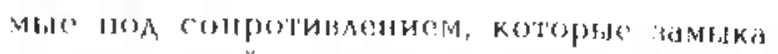

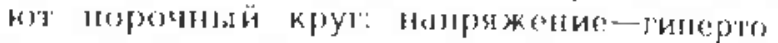

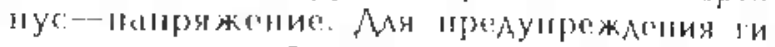

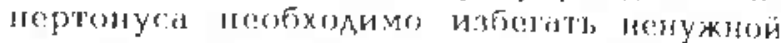

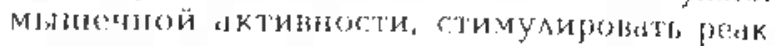

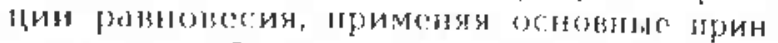

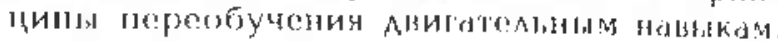

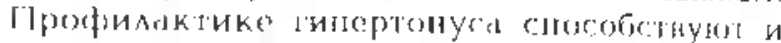

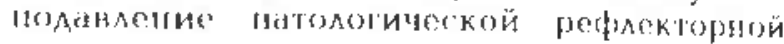

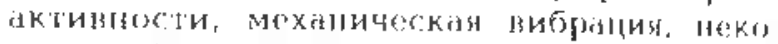

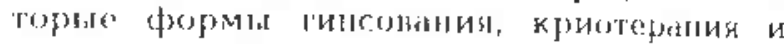

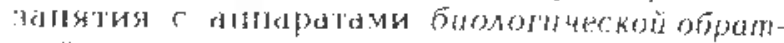
Hoй сHSt3B.

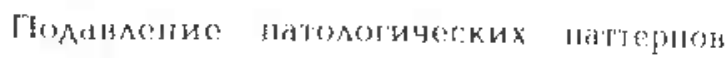

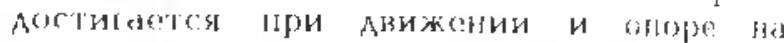

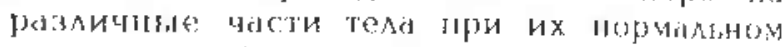

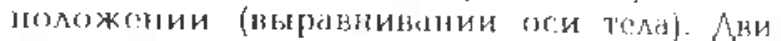

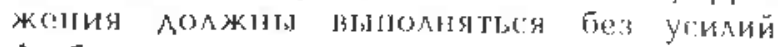
Агбов усияие пронопирует усиление пону са, реализуюгесея посредством содружест

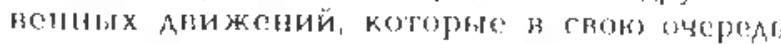

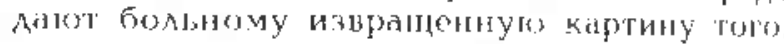

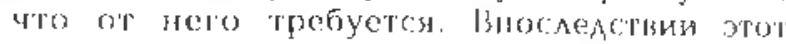

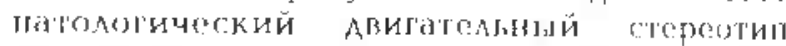

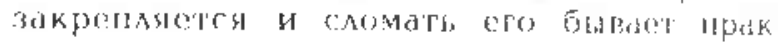

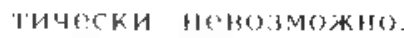

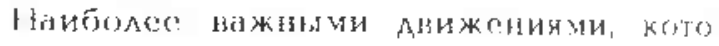

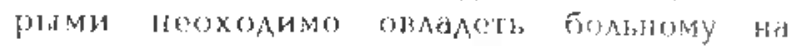

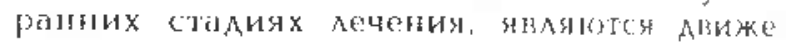
вия пвтоматическов прислособления $\mathrm{K}$ перемецценило центре тяжести и другие

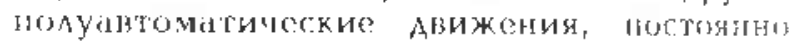

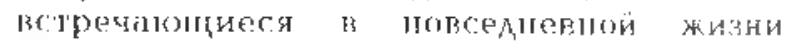

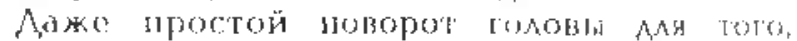

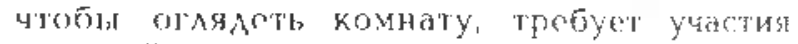
редкций равнонескя.

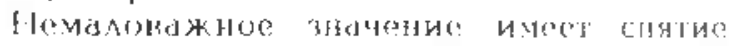

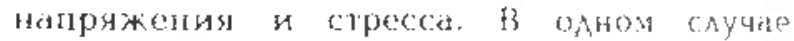

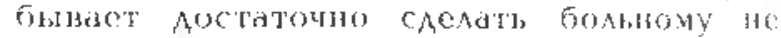

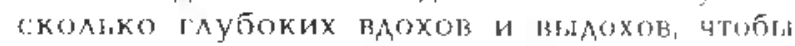

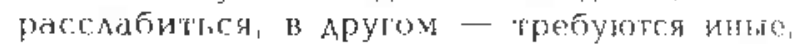
более сложние мегоды. Необходино аля кажАото конкретного боль!н10 полобрат, адекватиый способ рехаксации и ббуғить его расолабленин. Во время занятий

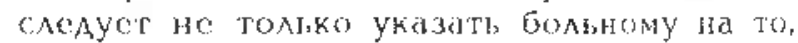
что тот налряжен, Асмонстрироваты тто на

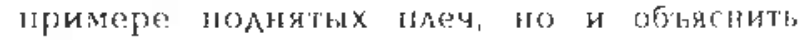

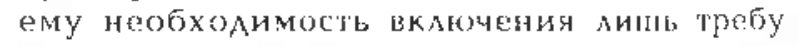

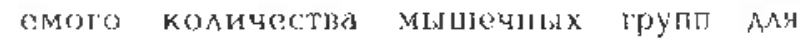
соверाпения опредслениоло Авижсния. Тан

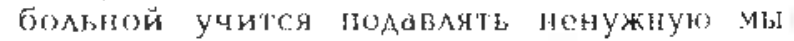

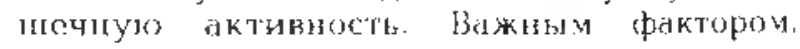

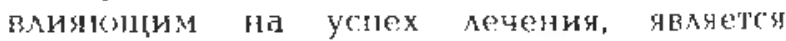
нербальная обратная сиязи.

Рефлекторвое подавление патологической импульсацим. Сущестгуют модели мізи желия, оказынакпис влияние па титерто нус, согровождаюций церебральные уров

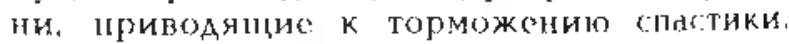
Сконцентриронаннце В прокснмальных отделах гулоница. они оказываются более эффектилавыми.

Именотя базисныс рефлекторно гормо зяпце спастику Авижения, то они вгегАа 


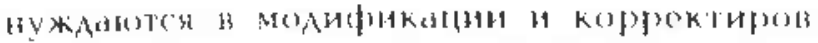

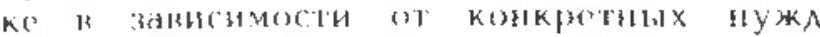

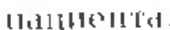

17 म

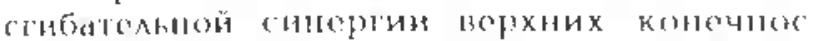

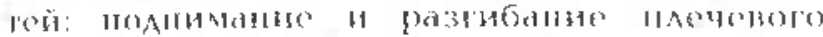

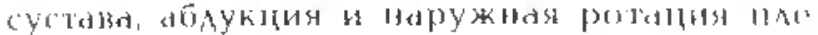

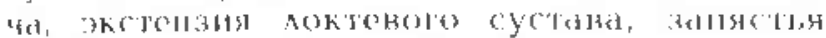

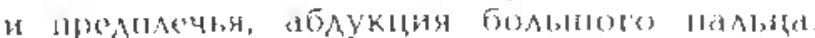

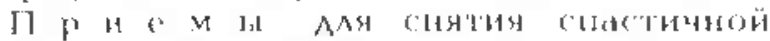

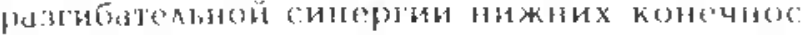

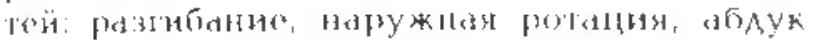
स्दु

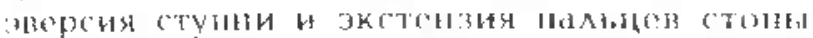

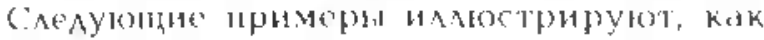

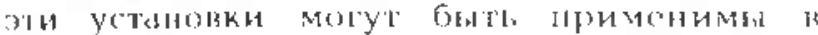

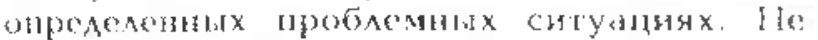

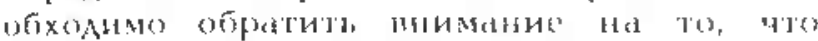

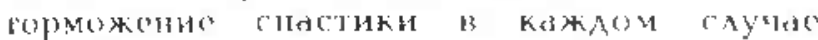

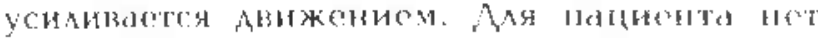
tI0,

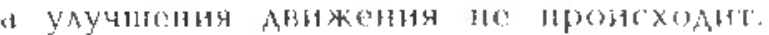

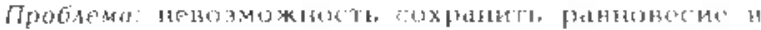

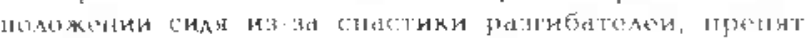

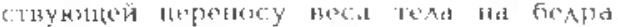

$\therefore$ क्ष

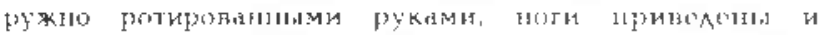

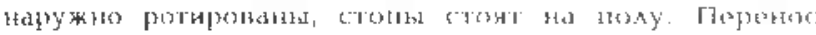

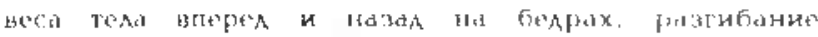

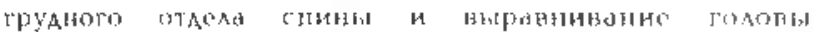

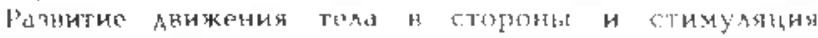

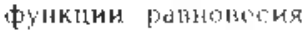

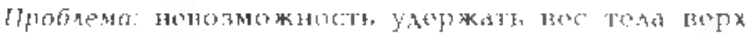

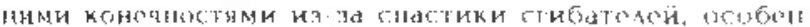

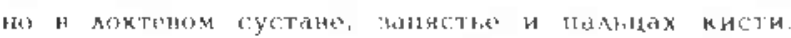

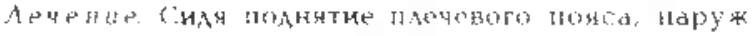

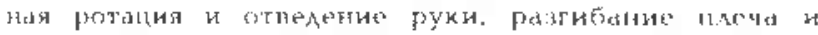

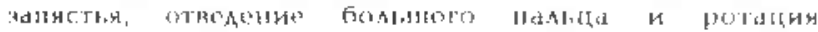

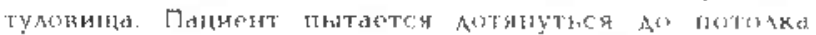

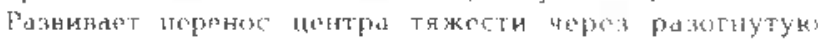

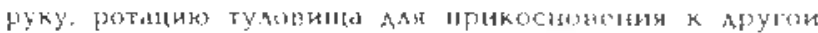
py'kt

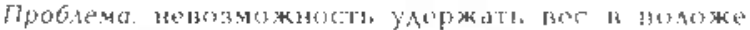

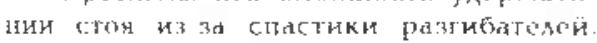

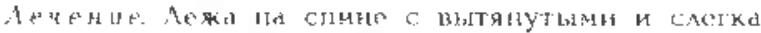

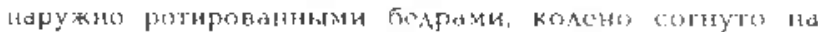

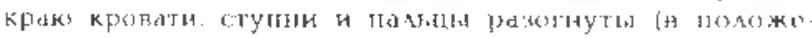

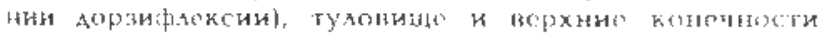

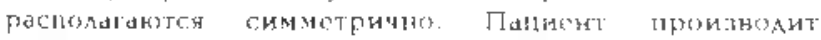

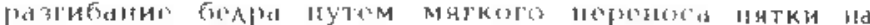

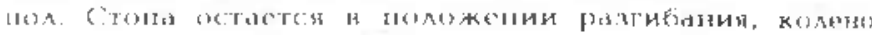

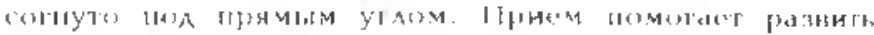

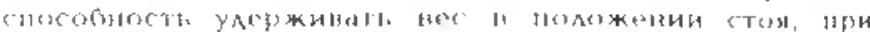

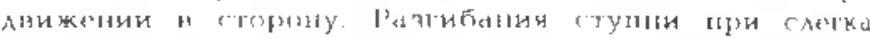

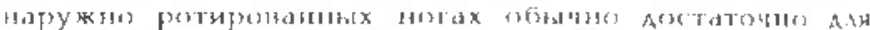

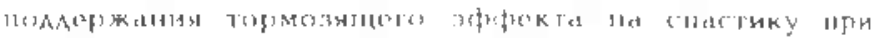

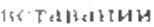

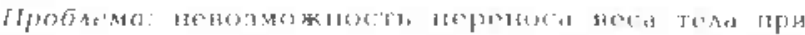

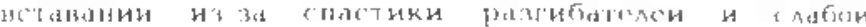

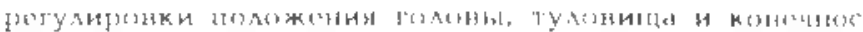

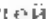

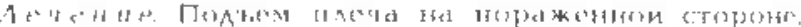

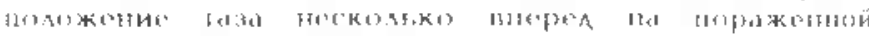

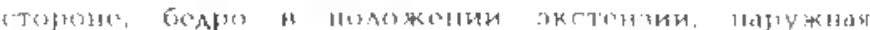

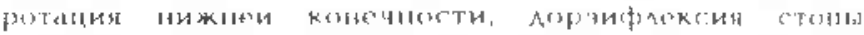

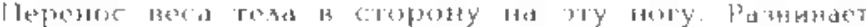

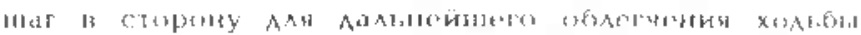

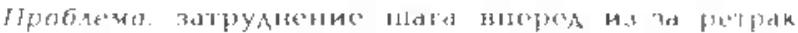

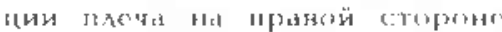

A t.

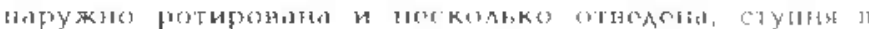

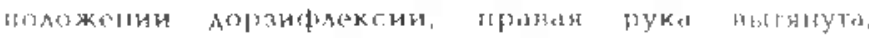

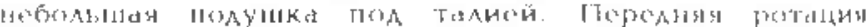

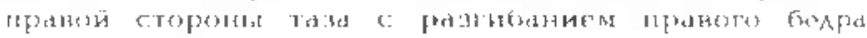

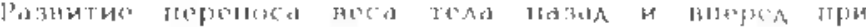

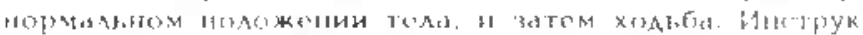

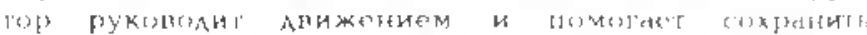

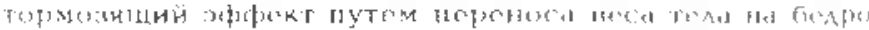

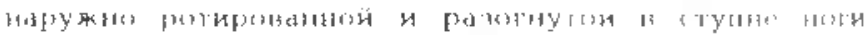

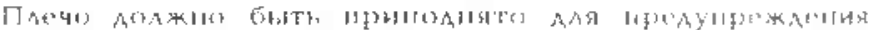
(“)

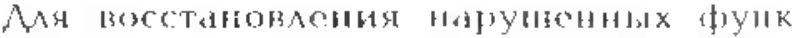
ций также применякте Я

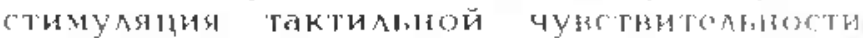

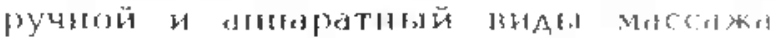

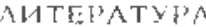

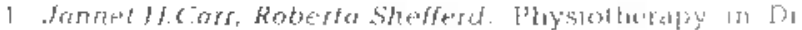

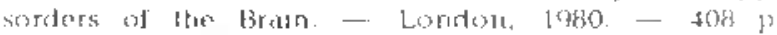

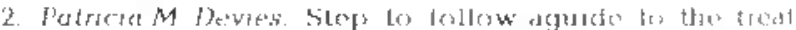

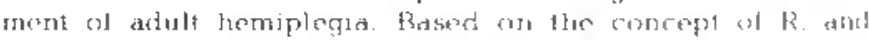

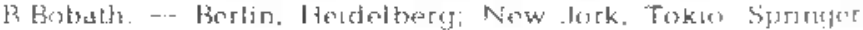
Verlata, 196s. - 291 p 